\title{
Impact of teacher training in conservation education on student learning in primary schools adjacent to Kibale National Park, Uganda
}

\author{
Kristen E. Lukas, Austin Leeds, Michelle A. Slavin \\ JOHN TINKA and CORINNE J. KENDALL
}

\begin{abstract}
Conservation education requires a multidisciplinary approach that ideally incorporates iterative monitoring to inform decision making and facilitate achievement of conservation goals. Despite their value and importance, evaluations of conservation education programmes are often challenging to conduct, and are published infrequently. In this study the impact of teacher training on student learning of environmental conservation concepts was assessed in students at 10 schools within $5 \mathrm{~km}$ of Kibale National Park, Uganda. Student surveys were administered at the beginning and end of each of 3 school years, throughout which teachers engaged in conservation education training. Results suggest students' conservation knowledge (e.g. knowing which species live in Kibale National Park, and how students themselves could help conserve wildlife) increased throughout each school year, but there were mixed results regarding the extent to which students showed improved understanding of the environmental problems threatening wildlife, and the reasons underlying the importance of conserving the Park. Understanding student knowledge gains and attitude shifts associated with teacher training in conservation education is important for knowing whether focusing on teachers contributes to intended impacts on student learning. Additional research on outcomes associated with long-term conservation education programmes will be useful for continuing to identify best practices in wildlife conservation.
\end{abstract}

Keywords Africa, conservation education, evaluation, human dimensions, knowledge, training, Uganda, wildlife

Supplementary material for this article can be found at https://doi.org/10.1017/So030605317000965

\footnotetext{
KRISTEN E. LUKAS (Corresponding author) and AUSTIN LeEDS Cleveland Metroparks Zoo, Cleveland, Ohio, USA, and Case Western Reserve University, Cleveland, Ohio, USA. E-mail kel@clevelandmetroparks.com

Michelle A. Slavin United States Peace Corps, Kingston, Jamaica

JoHn TINKA North Carolina Zoo's UNITE for the Environment, Bigodi, Uganda

Corinne J. Kendall North Carolina Zoo, Asheboro, North Carolina, USA

Received 16 December 2016. Revision requested 9 March 2017.

Accepted 2 June 2017. First published online 27 November 2017.
}

\section{Introduction}

Conservation of wildlife requires a multifaceted ap$\checkmark$ proach that often includes establishment of protected areas, ongoing monitoring and protection, reliable enforcement of wildlife laws, and engagement with communities to strengthen awareness and enhance implementation of relevant conservation initiatives. Given the importance of addressing human dimensions of conservation, conservation education may also be essential for species conservation (Washington et al., 2015). Conservation education programmes occur widely in Africa (e.g. Bettinger et al., 2010; Wallis \& Lonsdorf, 2010; Wright, 2010; Kling \& Hopkins, 2015) but are often secondary to wildlife research or other conservation programmes.

Broadly speaking, the goals of conservation education and outreach programmes are to increase knowledge about wildlife and conservation issues, help form or strengthen pro-environmental attitudes among target audiences, and facilitate behaviours that ultimately protect wildlife (Kuhar et al., 2010). In situ conservation education efforts target people living near threatened wildlife and may be particularly effective in rural areas, where access to conservation information is generally lacking. For instance, Kuhar et al. (2010) and Rakotomamonjy et al. (2015) have reported long-term impacts on environmental knowledge and conservation attitudes from in situ education programmes in rural areas.

Wildlife conservation requires continual evaluation to inform programme improvements and to ensure conservation targets are reached (Sutherland et al., 2004). Evaluation should be an integral part of the development and implementation of education programmes. However, evaluations are published infrequently and often ignored entirely because of a lack of resources or knowledge and an assumption that any intervention is better than none (Bettinger et al., 2010; Carleton-Hug \& Hug, 2010; Kling \& Hopkins, 2015). Successful conservation education programming requires that activities are in line with overall programme objectives (Heimlich, 2010; Kling \& Hopkins, 2015), align with the cultural context (Waylen et al., 2010), and actively engage the community (Waylen et al., 2010).

In Uganda, a country with abundant biodiversity, environmental education is part of the national curriculum and therefore presents an opportunity for collaboration between 
conservation educators and communities living near freeranging wildlife. However, a lack of training opportunities for teachers in environmental topics creates a barrier to the integration of conservation education. Lack of appropriate teaching materials for environmental education further exacerbates this barrier (Taylor, 1998). Thus, there is a need for more in-service teacher training in Uganda to help teachers address changes in the national curriculum and pedagogical practices (Altinyelken, 2010).

Kibale National Park is home to Africa's largest known population of eastern chimpanzees Pan troglodytes schweinfurthii as well as the most diverse population of primates on the continent. Uganda's population growth rate of $3.4 \%$, the fourth highest in the world, places increasing pressure on the Park's natural resources (Naughton-Treves et al., 2011). Since 2009, North Carolina Zoo's UNITE for the Environment (UNITE) programme has been working with 11 primary schools to the south of the Park to address pressing environmental challenges. UNITE's mission is to conserve wildlife habitats by inspiring the next generation of conservationists and fostering an appreciation of nature and wildlife in rural communities.

The programme's approach involves teacher training and student field trips aimed at improving teachers' capacity to provide student-centred lessons on conservation topics, with the ultimate goal of enhancing students' knowledge and attitudes towards the environment. UNITE emphasizes the use of student-centred teaching methods and provides teachers with training manuals and supplies necessary to implement activities. By working with local schools and administrators to implement programming, UNITE's approach to conservation education is in line with literature that suggests longer-term conservation education may be made more effective by integrating conservation education into school systems (Dolins et al., 2010).

A key component of UNITE is evaluation, including classroom observations, and student and teacher questionnaires. Because there are only a few published studies evaluating the effects of long-term in situ conservation education programmes, specifically teacher training and field trips, in developing nations, these practices are a significant aid to understanding the impacts of UNITE and other conservation education programmes. Our focus was to assess how the UNITE model of teacher training and field trips influenced student learning over time in rural communities bordering Kibale National Park, using beginning and end of year student questionnaires. We predicted that (1) students would demonstrate increases in conservation knowledge in four areas by the end of each school year: animals living in the Park, environmental problems in the Park, how students can help conserve the Park, and the importance of conserving the Park; (2) similar levels of learning would be achieved by students in Primary Three $\left(\mathrm{P}_{3}, c .9\right.$ years old) and Primary Six (P6, c. 13 years old); and (3) student learning would increase across years, as the impact of attendance at training by teachers should be cumulative across years.

\section{Methods}

\section{The UNITE model: teacher training and field trips}

Six teacher training sessions on three topics were provided to primary and secondary school teachers at 11 UNITE schools each year during 2009-2014. Student learning in 2012, 2013 and 2014 was analysed, and information from training during 2011-2014 was considered relevant to the analysis. Training topics were chosen by teachers and changed each term (2011 topics: Kibale National Park, human-wildlife conflict, population growth; 2012 topics: water conservation, sustainable agriculture, teaching methods; 2013 topics: great apes, alternative energy, bee-keeping; 2014 topics: wildlife of the Park, sustainable agriculture, biogas). Teachers were not paid to attend the training but were provided with a transportation refund, lunch, and accommodation if necessary. To supplement training provided to teachers, students in $\mathrm{P}_{5}, \mathrm{P} 6$ and $\mathrm{P}_{7}$ were taken on field trips to nearby natural areas (e.g. Bigodi Wetlands). Training materials were developed in advance in conjunction with local experts familiar with the Ugandan national curriculum. In addition, evaluations of the teachers' experience during training were conducted immediately before and after training workshops to ensure teachers were satisfied with the training programme and acquired the intended knowledge.

\section{Student evaluations}

To determine if teachers' conservation knowledge was being transferred to students, UNITE staff evaluated $\mathrm{P}_{3}$ and $\mathrm{P} 6$ students at the beginning and end of each school year, using questionnaires that included questions about knowledge and attitude. For both classes the administrators read questions aloud in both Rutooro (the dominant local language in the region) and English. Additional terms were used to identify key items if students did not understand the question; however, definitions were never provided to students to help them understand, as this would have interfered with the assessment of student knowledge. From 2010 to 2013 all students in class were evaluated but in 2014 only every fifth student was evaluated in classrooms with $>100$ children. For smaller classes, we either evaluated all students or selected at least 25 students at random. To ensure teachers did not guide students, administrators asked them to leave the classroom during evaluation.

Survey questions changed based on the training topics for each year, but the following questions were asked consistently of UNITE school students in $\mathrm{P}_{3}$ and $\mathrm{P} 6$ classrooms 
at the beginning and end of each academic year (preand post-teaching) during 2012-2014 (Supplementary Material): (1) Which animals live in Kibale National Park? (2) What environmental problems are present in Kibale National Park? (3) How can you help Kibale National Park? (4) Why is it important to conserve Kibale National Park?

The first three questions evaluated increases in knowledge about local wildlife, threats to wildlife, and ways to help wildlife. The fourth question evaluated students' attitudes towards biodiversity conservation by identifying whether they provided pro-environmental or utilitarian reasons for conserving the Park. Questions were adapted from Kuhar et al. (2007).

As only one secondary school participated in UNITE during 2011-2014, this analysis focuses exclusively on $\mathrm{P}_{3}$ and P6 classrooms in 10 schools (Table 1). Teachers assigned to all primary classrooms at these schools attended UNITE training during 2011-2014 (C.J. Kendall et al., unpubl. data). All training included information tested by the four survey questions. In Uganda a single teacher teaches multiple age groups, in either lower primary $\left(\mathrm{P}_{1}-\mathrm{P}_{4}\right)$ or upper primary $\left(\mathrm{P}_{5}-\mathrm{P}_{7}\right)$, so students may have interacted with a given teacher across multiple years.

For questions 1, 2 and 3 we treated each response option separately and summed the total score for each question. Students received a score of +1 for circling each correct response and not circling each incorrect response. Students received a score of -1 for circling an incorrect response or failing to circle a correct response. Question 1 had eight response options, with a scoring range of -8 (all incorrect) to +8 (all correct). Questions 2-3 had six response options, with a scoring range of -6 to +6 . Question 4 was an open question, and each response was characterized as Desirable (helpful to environment, legal) or Undesirable (harmful to environment, illegal). A survey with one or more Desirable and no Undesirable responses was coded as +1 ; a survey with both Desirable and Undesirable responses was coded as o; and a survey with one or more Undesirable responses and no Desirable responses was coded as -1 .

\section{Data analysis}

Surveys did not contain identifying information, and therefore we could not conduct paired comparisons by student. We conducted independent sample two-tailed $t$-tests with unequal variance to compare mean scores for each question by year and grade level in pre- vs post-teaching conditions. To calculate mean scores we averaged across all students for each school and grade by question. Pre- and post-teaching responses are reported as mean \pm SE scores. Alpha was set at 0.05 , and trends are reported where $\mathrm{P}<0.10$. Statistical analysis was conducted in SPSS v. 23 (IBM, Armonk, USA).
Protocols for this research were approved by the North Carolina Zoo and complied with the laws of Uganda. All questionnaires were completed anonymously.

\section{Results}

A total of 3,874 surveys were completed in 10 UNITE schools during 2012-2014 (Table 1).

\section{Question 1: Which animals live in Kibale National Park?}

Both $\mathrm{P}_{3}$ and P6 students could identify significantly more animals living in the Park at the end of the school year compared to the beginning of the year (Fig. 1a). Except for $\mathrm{P}_{3}$ students in 2012, there was a significant increase in the mean number of correct responses to this question for $\mathrm{P}_{3}$ and P6 students (Fig. 1a). The top three animals selected by $\mathrm{P}_{3}$ students at the end of the school year were elephant (Loxodonta africana, $82 \%$ of students), chimpanzee (Pan troglodytes, $72 \%$ ) and buffalo (Syncerus caffer, $61 \%$ ), and by P6 students were chimpanzee (93\%), elephant (85\%) and crested crane (Balearica regulorum, $78 \%$ ).

Question 2: What environmental problems are present in Kibale National Park? Overall, P6 students could identify significantly more environmental problems in the Park at the end of the school year compared to the beginning, but there was only a trend towards an increase for $\mathrm{P}_{3}$ students (Fig. 1b). There was a significant increase in the mean number of correct responses to this question for both $\mathrm{P}_{3}$ and P6 students in 2012 and for $\mathrm{P}_{3}$ students in 2014. $\mathrm{P}_{3}$ students showed a significant decrease in correct responses in 2013, and there were no changes in P6 students in 2013 and 2014. Top responses selected by $\mathrm{P}_{3}$ students at the end of the school year were deforestation ( $80 \%$ of students), burning ( $73 \%)$, overgrazing (66\%) and poaching $(66 \%)$. The top three responses selected by P6 students at the end of the school year were poaching ( $87 \%$ of students), deforestation ( $81 \%)$ and burning $(76 \%)$.

Question 3: How can you help Kibale National Park? $\mathrm{P}_{3}$ students reported more ways they could help the Park at the end of the school year than at the beginning (Fig. 1c). In contrast, P6 students showed no change in the number of correct responses provided at the end of the school year. There was a significant increase in the mean number of correct responses to this question for $\mathrm{P}_{3}$ students in all 3 years and for P6 students in 2014. P6 students showed no change in correct responses to this question in 2012 or 2013. Both $\mathrm{P}_{3}$ and P6 students had the most correct responses in 2014, and there was an increasing trend in correct responses across all 3 years for P6 students 
TABLE 1 Number of students surveyed in grades $\mathrm{P}_{3}$ and P6 at the beginning (pre) and end (post) of each school year during 2012-2014. The students were from 10 primary schools in rural communities on the south side of Kibale National Park, Uganda, participating in North Carolina Zoo's UNITE for the Environment programme. Blank cells indicate missing data.

\begin{tabular}{|c|c|c|c|c|c|c|c|c|c|c|c|c|}
\hline \multirow[b]{3}{*}{ School } & \multicolumn{4}{|l|}{2012} & \multicolumn{4}{|c|}{2013} & \multicolumn{4}{|c|}{2014} \\
\hline & \multicolumn{2}{|l|}{ P3 } & \multicolumn{2}{|l|}{ P6 } & \multicolumn{2}{|l|}{ P3 } & \multicolumn{2}{|l|}{ P6 } & \multicolumn{2}{|l|}{ P3 } & \multicolumn{2}{|l|}{ P6 } \\
\hline & Pre & Post & Pre & Post & Pre & Post & Pre & Post & Pre & Post & Pre & Post \\
\hline Bigodi Primary School & 69 & 59 & 52 & 45 & 67 & 58 & 51 & 63 & 11 & 6 & 8 & 5 \\
\hline Bigodi Women's Progressive & 32 & 28 & 15 & 15 & 33 & 33 & 22 & 17 & 10 & 10 & 6 & 21 \\
\hline Bunoga Primary School & 86 & 82 & 37 & 43 & 79 & 85 & 46 & 40 & 13 & 13 & 7 & 9 \\
\hline Busabura Primary School & 47 & 55 & 22 & 15 & 39 & 50 & 22 & 19 & 11 & 9 & 4 & 15 \\
\hline Busiriba Primary School & 115 & 111 & 88 & 74 & 140 & 144 & 86 & 84 & 28 & 19 & 18 & 15 \\
\hline Kinoni 'K’ Primary School & 28 & 25 & & & 25 & 19 & & & 6 & 6 & 6 & 6 \\
\hline Kioyima Primary School & 19 & 19 & 41 & 34 & 30 & 27 & 27 & 24 & 7 & 11 & 5 & 22 \\
\hline Kyakagunga Primary School & & & & & 16 & 10 & 11 & 7 & 3 & 12 & 9 & 3 \\
\hline Rugonjo Primary School & 53 & 46 & 49 & 39 & 45 & 76 & 31 & 44 & 11 & 9 & 7 & 6 \\
\hline Rwengobe Primary School & 67 & 55 & 55 & 45 & 56 & 47 & 54 & 55 & 15 & 17 & 14 & 14 \\
\hline Total & 516 & 480 & 359 & 310 & 530 & 549 & 350 & 353 & 115 & 112 & 84 & 116 \\
\hline
\end{tabular}

(Fig. 1c). The top three responses selected by $\mathrm{P}_{3}$ students at the end of the school year were not to enter the Park without permission ( $75 \%$ of students), not to wash in the river (66\%), and not to throw buvera (polythene bags)/ plastic (65\%), and by P6 students were not to enter the Park without permission (78\%), to educate friends and family about the environment $(76 \%)$, and not to wash in the river $(60 \%)$. In 2014 only, the frequency of both $\mathrm{P}_{3}$ (64-86\%) and P6 students (81-91\%) responding that they could help the Park by educating friends and family about the environment increased.

Question 4: Why is it important to conserve Kibale National Park? $\mathrm{P}_{3}$ students showed a significant increase in correct responses to this question at the end of the school year compared to the beginning (Fig. 1d). In contrast, P6 students showed no change in the number of correct responses to this question at the end of the school year. For $\mathrm{P}_{3}$ students, the number of correct responses increased in 2012 and 2013 but not in 2014. In contrast, P6 students showed no change in correct responses to this question in any year. The top five responses offered by $\mathrm{P}_{3}$ students at the end of the school year were trees/plants (36\% of students), home for animals (21\%), protect environment/animals (19\%), rainfall/protect from drought (4\%), and protect from deforestation (3\%). The greatest increase for $\mathrm{P}_{3}$ students was in identifying the Park as a home for animals (from 1 to $21 \%$ ). The top five responses offered by P6 students at the end of the school year were tourism ( $45 \%$ of students), home for animals $(23 \%)$, source of income $(20 \%)$, rainfall/protect from drought (16\%), and oxygen (10\%). The greatest increase for P6 students was in identifying the Park as a place for tourism (from 34 to $45 \%$ ).

\section{Discussion}

We evaluated student learning outcomes associated with environmental education training provided to teachers in 10 primary schools adjacent to Kibale National Park in Uganda. We found students in the UNITE programme during 2012-2014 demonstrated increases in conservation knowledge, such as which species live in the Park, and how students themselves could help conserve wildlife. However, there were mixed results on the extent to which students showed improvement in understanding the environmental problems threatening wildlife conservation and the reasons underlying the importance of conserving the Park. In an associated analysis of teacher performance at these schools, teachers who attended at least three training sessions per year showed significantly more integration of environmental education concepts in their teaching than those who did not (C.J. Kendall et al., unpubl. data). These results are useful for determining whether teacher training in conservation education contributes to intended impacts on student learning.

\section{Did students' conservation knowledge increase} throughout the course of each school year?

Students demonstrated some increases in conservation knowledge between the beginning and end of school years during which their teachers participated in conservation education training, although there was some variation between grades and years.

\section{Did P3 and P6 students show similar gains in conservation knowledge?}

Overall, there were differences in conservation knowledge and gains in conservation knowledge between $\mathrm{P}_{3}$ and $\mathrm{P} 6$ 

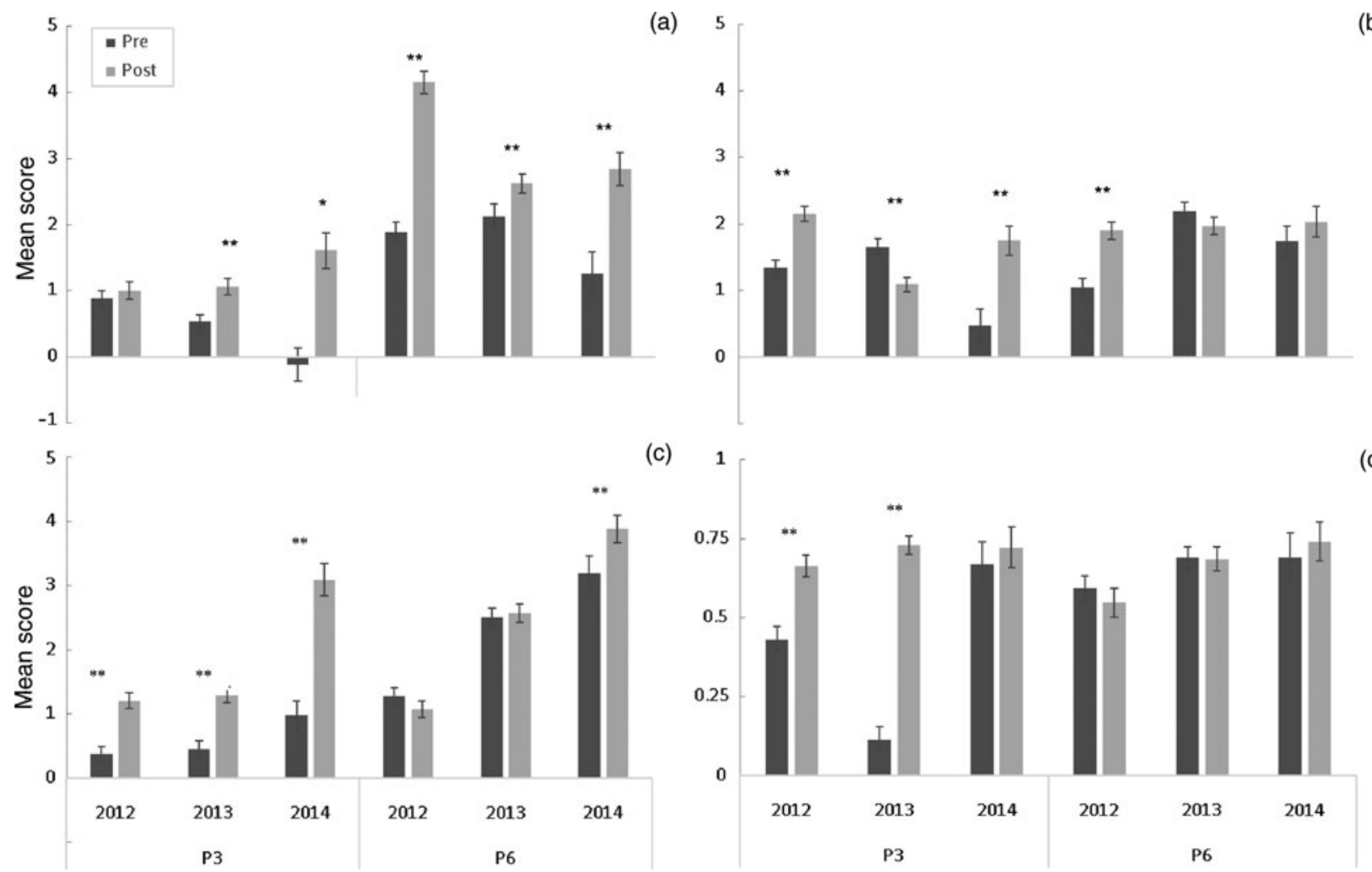

(b)

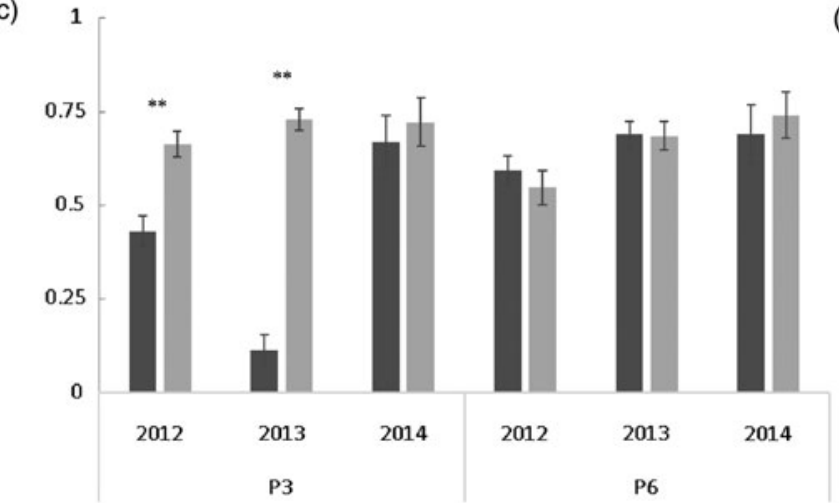

Fig. 1 Mean scores for survey questions administered to students in $\mathrm{P}_{3}$ and $\mathrm{P} 6$ in 10 primary schools in rural communities on the south side of Kibale National Park, Uganda, surveyed at the beginning (pre) and end (post) of the school year during $2012-2014$. (a) What animals live in Kibale National Park? (range -8 , all incorrect, to 8, all correct). Across all 3 years (with the exception of $\mathrm{P}_{3}$ students in 2012, $t=-0.74, \mathrm{df}=983, \mathrm{P}=0.46)$ there was a significant increase in the mean number of correct responses $\left(\mathrm{P}_{3_{2013}}\right.$ : $t=-4.62, \mathrm{df}=223, \mathrm{P}<0.001 ; \mathrm{P}_{32014}: t=-2.09, \mathrm{df}=684, \mathrm{P}=0.04 ; \mathrm{P}_{2012}: t=-3.27, \mathrm{df}=1073, \mathrm{P}=0.001 ; \mathrm{P}_{2013}: t=-9.87, \mathrm{df}=639$, $\mathrm{P}<0.001 ; \mathrm{P}_{2014}: t=-3.80, \mathrm{df}=166, \mathrm{P}<0.001$ ). (b) What are the environmental problems in Kibale National Park? (range -6 , all incorrect, to 6, all correct). There was a significant increase in the mean number of correct responses in 2012 for both $\mathrm{P}_{3}$ and $\mathrm{P} 6$ $\left(\mathrm{P}_{3_{2012}}: t=-4.89, \mathrm{df}=989, \mathrm{P}<0.001 ; \mathrm{P}_{2012}: t=-4.63, \mathrm{df}=666, \mathrm{P}<0.001\right)$ and in 2014 for $\mathrm{P}_{3}$ only $\left(\mathrm{P}_{32014}: t=-3.84, \mathrm{df}=222\right.$, $\mathrm{P}<0.001)$ but a decrease in 2013 for $\mathrm{P}_{3}$ students $\left(\mathrm{P}_{3_{2013}}: t=3.60, \mathrm{df}=1068, \mathrm{P}<0.001\right)$. (c) How can you help Kibale National Park? (range -6 , all incorrect, to 6, all correct). The number of correct responses from $\mathrm{P}_{3}$ students increased in all 3 years $\left(\mathrm{P}_{3_{2012}}: t=-5.01\right.$, $\mathrm{df}=990, \mathrm{P}<0.001 ; \mathrm{P}_{3_{2013}}: t=-5.14, \mathrm{df}=1077, \mathrm{P}<0.001 ; \mathrm{P}_{3_{2014}}: t=-6.39, \mathrm{df}=215, \mathrm{P}<0.001$ ), whereas there was a significant increase in correct responses from $\mathrm{P} 6$ students only at the end of the 2014 school year $\left(\mathrm{P}_{2012}: t=1.09, \mathrm{df}=662, \mathrm{P}=0.28 ; \mathrm{P} 6_{2013}\right.$ : $\left.t=-0.32, \mathrm{df}=696, \mathrm{P}=0.75 ; \mathrm{P}_{2014}: t=-2.01, \mathrm{df}=168, \mathrm{P}<0.05\right)$. (d) Why is it important to conserve Kibale National Park? (range 0 , all incorrect, to 1, all correct). The number of correct responses from $\mathrm{P}_{3}$ students increased in 2012 and $2013\left(\mathrm{P}_{3_{2012}}: t=-5.01, \mathrm{df}=981\right.$, $\mathrm{P}<$ o.001; $\left.\mathrm{P}_{3_{2013}}: t=-11.82, \mathrm{df}=932, \mathrm{P}<0.001\right)$.

students, but $\mathrm{P}_{3}$ and $\mathrm{P} 6$ students showed similar gains in knowledge of the wildlife living in Kibale National Park. On average, $\mathrm{P}_{3}$ students started with a lower number of correct responses but almost doubled the number throughout the school year, whereas P6 students increased their number of correct responses to Question 1 from two to three. Comparing end-of-the-year responses, $\mathrm{P}_{3}$ students most frequently reported that elephants, followed by chimpanzees, lived in the Park. In contrast, nearly all P6 students most frequently reported that chimpanzees, followed by elephants, lived in the Park. This difference in emphasis between $\mathrm{P}_{3}$ and $\mathrm{P} 6$ students may be explained by the fact that elephants are huge mammals and exciting for young children. The impact of elephants may be more evident to even the youngest members of the community as a result of crop raiding. In contrast, older children may more readily identify chimpanzees because of their conservation status and being a tourist attraction (Archabald \& NaughtonTreves, 2001). In addition, conservation films featuring Uganda's apes were shown to $\mathrm{P} 6$ but not $\mathrm{P}_{3}$ students in these schools during 2013-2014 and may have contributed to student learning in this timeframe (Leeds et al., 2017).

Regarding knowledge of environmental problems in the Park, P6 students showed significant gains but there was only a trend towards an increase for $\mathrm{P}_{3}$ students. At the end of the school year $\mathrm{P}_{3}$ students most frequently reported deforestation, followed by bush burning, as a threat to wildlife in the Park. In contrast, poaching was most frequently cited by students at the P6 level, followed by deforestation and then bush burning. This may be explained by the curriculum, in which 
teachers provide age-appropriate conservation education that focuses on the importance of planting trees to reduce deforestation for younger students, and postpone discussions of threats such as poaching until students are older. There is also evidence that communities around the Park are familiar with environmental resource scarcity (Hartter et al., 2011), and therefore students may gain knowledge through conversations occurring outside the classroom.

On average, $\mathrm{P}_{3}$ students exhibited more gains in knowledge of ways they could help the Park than did P6 students. Students at both levels were most likely to report not entering the Park without permission and not washing in the river as ways to help the Park. $\mathrm{P}_{3}$ students were also more likely to cite the importance of not littering than P6 students. At the end of the school year $>75 \%$ of P6 students understood their role in educating friends and family about the environment. Both $\mathrm{P}_{3}$ and $\mathrm{P} 6$ students were more likely to respond that they could help the Park by educating friends and family about the environment at the end of the school year than at the beginning, suggesting they may have felt more empowered to share their knowledge at the end of the school year. This appreciation of the role that they, as young adults, could play in influencing the knowledge, and perhaps attitudes and behaviours, of people within their circle of influence is a promising finding for reinforcing the potential for extended impacts of in-school conservation education programmes (Damerell et al., 2013).

On average, $\mathrm{P}_{3}$ students exhibited more gains in knowledge of the importance of conserving the Park than P6 students. This may have been because P6 students were already well informed about the importance of conserving the Park at the start of the school year and therefore there was limited scope for increasing their knowledge throughout the year; for example, 93\% (418 of 449) of the responses provided by P6 students at the start of the school year could be categorized as desirable (positive, legal) reasons for conserving the Park, compared to $95 \%$ at the end of the year.

Differences in attitudes to conservation may be revealed by the various perspectives evident in the responses provided to this question. The younger $\left(\mathrm{P}_{3}\right)$ students cited more intrinsic or naturalistic reasons for protecting the Park, focusing primarily on the presence of plants and animals that require protection. In contrast, the older (P6) students primarily cited tourism, indicating a more utilitarian perspective that considers the economic benefits of preserving the Park. Older students also exhibited a utilitarian attitude by acknowledging the ecological benefits of a forest, including rainfall, protection from drought, and provision of oxygen.

\section{Did students' conservation knowledge increase across} the 3 years of the study?

Although students demonstrated reliable increases in knowledge between the beginning and end of the school year for most survey questions in most years, the only linear increase over time was in the mean number of correct responses to the question 'How can you help Kibale National Park?', particularly for P6 students. On average, both $\mathrm{P}_{3}$ and $\mathrm{P} 6$ students provided one correct response to this question in 2012 but this increased to three or more correct responses in 2014. This may be attributable to the emphasis on teaching topics such as energy conservation, and providing training to teachers on sustainable activities such as bee-keeping, keyhole gardens and fuel-efficient stoves. The programme's emphasis on these topics may lead to students gaining a greater appreciation of how they can reduce their impact on the Park, with more ideas on ways they can reduce their impact each year. This question may thus allow for greater development in students over time compared to the other questions.

\section{Teacher training and student learning}

Conservation education needs to address decision making and critical thinking skills to encourage the adoption of environmentally friendly behaviour while remaining culturally and socially relevant (Heimlich, 2010; Waylen et al., 2010). Providing conservation education training to teachers in rural communities is one way to integrate knowledge and resources into an existing framework for change (Rakotomamonjy et al., 2015). We found that teacher training was associated with improved student learning in a long-term conservation education programme in Uganda. Although various teacher, student and familial characteristics influence student achievement, the assumption that training improves teaching, and that better teaching leads to improvements in student learning (Kennedy, 1998, p. 14; Westbrook et al., 2013, p. 43), has been supported by researchers internationally (Jerusalem: Angrist \& Lavy, 2001; France: Bressoux, 1996; USA: Darling-Hammond, 2000). When combined with field trips and other learning tools, such as conservation films (e.g. Leeds et al., 2017), teacher training may be an efficient and cost-effective way to positively influence conservation knowledge in students. Particularly in rural areas, teachers tend to be respected leaders in the community and can influence not only the students they interact with daily but members of an entire village. As environmental education concepts may be transmitted between generations (Damerell et al., 2013), teacher training has the potential to influence learning of teachers, students and even at the household and community levels.

C.J. Kendall et al. (unpubl. data) found that teachers attending UNITE training integrated environmental education information into the classroom more often than those who did not attend training frequently during this study. As teacher training included examples of using locally available resources and employed student-centred activities, teachers were familiar with tools that they could use to help 
convey environmental topics in subjects as diverse as mathematics, science, religion and social studies. Although the educational structure of the Ugandan school system prevented C.J. Kendall et al. (unpubl. data) from linking gains in teacher performance directly to student learning at the individual teacher/classroom level, we suggest that teacher training contributed to student learning about animals living in Kibale National Park, environmental problems in the Park, how students can help conserve the Park, and the importance of conserving the Park. We observed the greatest improvements in students' knowledge of animals and environmental problems, and UNITE training may have facilitated the integration of these topics into classroom lessons.

Although C.J. Kendall et al. (unpubl. data) found that teachers of lower primary classes generally performed better on measures of teacher performance (environmental education integration, quality of methods, and student-centred methods) than teachers of upper primary classes, students at both the $\mathrm{P}_{3}$ and $\mathrm{P} 6$ levels gained knowledge about which animals live in the Park, and environmental threats. In some cases we found that $\mathrm{P}_{3}$ students showed greater gains than P6 students, such as in reporting ways they themselves could help conserve the Park, and why conserving the Park was important. It is unclear whether the younger students simply had more scope for development or if there is perhaps a threshold that will require more training, motivation or innovation by trainers, teachers and/or students to surpass current levels in future years.

\section{Study limitations}

There was a myriad of potential influences on student learning during this study, including field trips for P6 students, film screenings, and conversations outside classrooms. In addition, we did not control for other inputs that may have fostered or impeded student learning over the course of each school year, such as class size, students' access to textbooks, and time spent on various topics (Nannyonjo, 2007), or variations in community events, access to radio, television and internet resources, or interactions with international tourists. It is therefore difficult to rule out the influence of other factors on knowledge gains reported here. Future studies should consider the use of control groups, as UNITE has started doing, for evaluation of programmes.

Our research did not specifically address differences in student outcomes based on teacher training in pedagogy vs specific conservation content areas. Pedagogical training may be an effective way to influence student learning outcomes (Darling-Hammond, 2000). However, an associated evaluation of teacher performance in these UNITE schools suggests that the improved student outcomes found here were probably facilitated by teachers' increased knowledge and teaching of environmental topics rather than changes in teaching style
(C.J. Kendall et al., unpubl. data). In addition, we don't know whether the teacher training or field trips were more important in leading to the outcomes discussed, although it is likely that both played a role. Future studies should include additional assessments of field trips and other associated programme elements to help identify how these various approaches may contribute to student learning.

\section{Conclusion}

Conservation education aims to increase pro-conservation knowledge, attitudes and behaviours. Although some authors caution against blanket assumptions that increasing environmental knowledge alone will change behaviour (Bride, 2006; Heimlich, 2010), there is some evidence to suggest that knowledge improves pro-environmental attitudes, which presumably precede pro-environmental behaviours (Damerell et al., 2013). Finding efficient and effective ways to strengthen the chain of relationships between knowledge, attitudes and behaviour (Kuhar et al., 2010) may be beneficial for increasing sustainable and environmental behaviours, particularly in rural communities in the vicinity of protected areas (Rakotomamonjy et al., 2015).

Students with awareness of environmental issues and concern for wildlife conservation become informed adult community members and perhaps even community leaders responsible for identifying and cultivating behaviours that help promote livelihoods, decrease environmental impact, reduce human-wildlife conflict, and promote conservation of wildlife. Successful integration of relevant environmental and conservation topics into the classroom through teacher training, as measured through iterative evaluation, may be one tool for efficiently reaching students and, perhaps, entire communities to achieve conservation goals.

\section{Acknowledgements}

We thank and acknowledge the Uganda Wildlife Authority, Donah Ndinawe, Katangole James, Bicweka Chance, Dr Randy Fulk, and the Kibale Association for Rural and Environmental Development. We thank especially Dr Rich Bergl for his vision and leadership. Financial support for UNITE was provided by North Carolina Zoo (NCZ), North Carolina Zoological Society, Association of Zoos and Aquarium Ape Conservation Initiative, and Disney Wildlife Conservation Fund. In-kind support for data analysis was provided by Cleveland Metroparks Zoo and NCZ, and we thank the volunteers who entered and coded surveys.

\section{Author contributions}

KEL conducted and provided oversight for data entry and analysis and served as primary author; KEL, AL and CJK 
developed research questions and collaborated on analysing data and interpreting results; AL entered and managed all data in Cleveland; MAS and TJ conducted all teacher training in Uganda; MAS provided oversight of UNITE activities, including teacher training, data collection and data management; TJ collected data, provided input on local context, and provided leadership in community relations; CJK provided direction for the project, and oversight of all UNITE activities. All authors contributed to the writing of the article.

\section{References}

Altinyelken, H.K. (2010) Curriculum change in Uganda: teacher perspectives on the new thematic curriculum. International Journal of Educational Development, 30, 151-161.

ANGRIST, J.D. \& LAVY, V. (2001) Does teacher training affect pupil learning? Evidence from matched comparisons in Jerusalem public schools. Journal of Labor Economics, 19, 343-369.

Archabald, K. \& Naughton-Treves, L. (2001) Tourism revenuesharing around national parks in Western Uganda: early efforts to identify and reward local communities. Environmental Conservation, 28, 135-149.

Bettinger, T.L., Kuhar, C.W., Lehnhardt, K., Cox, D. \& Cress, D. (2010) Discovering the unexpected: lessons learned from evaluating conservation education programs in Africa. American Journal of Primatology, 72, 445-449.

Bressoux, P. (1996) The effects of teachers' training on pupils' achievement: the case of elementary schools in France. School Effectiveness and School Improvement, 7, 252-279.

BRIDE, I. (2006) The conundrum of conservation education and the conservation mission. Conservation Biology, 20, 1337-1339.

Carleton-Hug, A. \& Hug, J.W. (2010) Challenges and opportunities for evaluating environmental education programs. Evaluation and Program Planning, 33, 159-164.

Damerell, P., Howe, C. \& Milner-Gulland, E.J. (2013) Child-orientated environmental education influences adult knowledge and household behaviour. Environmental Research Letters, 8, 015016, http://dx.doi.org/10.1088/1748-9326/8/1/015016.

DARLING-HAMMOND, L. (2000) How teacher education matters. Journal of Teacher Education, 51, 166-173.

Dolins, F.L., Jolly, A., Rasamimanana, H., Ratsimbazafy, J., Feistner, A.T.C. \& Ravoavy, F. (2010) Conservation education in Madagascar: three case studies in the biologically diverse islandcontinent. American Journal of Primatology, 72, 391-406.

Hartter, J., Goldman, A. \& Southworth, J. (2011) Responses by households to resource scarcity and human-wildlife conflict: issues of fortress conservation and the surrounding agricultural landscape. Journal for Nature Conservation, 19, 79-86.

Heimlich, J.E. (2010) Environmental education evaluation: reinterpreting education as a strategy for meeting mission. Evaluation and Program Planning, 33, 180-185.

Kennedy, M. (1998) Form and substance in inservice teacher education. Research Monograph No. 13. National Institute for Science Education, Madison, USA.

KLING, K.J. \& Hopkins, M.E. (2015) Are we making the grade? Practices and reported efficacy measures of primate conservation education programs. American Journal of Primatology, 77, 434-448.

Kuhar, C.W., Bettinger, T.L., Lehnhardt, K., Townsend, S. \& Cox, D. (2007) Evaluating the impact of a conservation education programme in the Kalinzu Forest Reserve, Uganda. International Zoo Educators Journal, 43, 12-15.

Kuhar, C.W., Bettinger, T.L., Lehnhardt, K., Tracy, O. \& Cox, D. (2010) Evaluating for long-term impact of an environmental education program at the Kalinzu Forest Reserve, Uganda. American Journal of Primatology, 72, 407-413.

Leeds, A., Lukas, K.E., Kendall, C.J., Slavin, M.A., Ross, E.A., Roввіns, M.M. et al. (2017) Evaluating the effect of a year-long film focused environmental education program on Ugandan student knowledge of and attitudes toward great apes. American Journal of Primatology, 79, e22673, https://doi.org/10.1002/ajp.22673.

Nannyonjo, H. (2007) Education Inputs in Uganda. An Analysis of Factors Influencing Learning Achievement in Grade Six. World Bank Working Paper No. 98. World Bank, Washington, DC, USA. Http:// dx.doi.org/10.1596/978-0-8213-7056-8.

Naughton-Treves, L., Alix-Garcia, J. \& Chapman, C.A. (2011) Lessons about parks and poverty from a decade of forest loss and economic growth around Kibale National Park, Uganda. Proceedings of the National Academy of Sciences of the United States of America, 108, 13919-13924.

RaKотоmamonjy, S.N., Jones, J.P.G., RazafimanahaKa, J.H., Ramamonjisoa, B. \& Williams, S.J. (2015) The effects of environmental education on children's and parents' knowledge and attitudes towards lemurs in rural Madagascar. Animal Conservation, $18,157-166$

Sutherland, W.J., Pullin, A.S., Dolman, P.M. \& Knight, T.M. (2004) The need for evidence-based conservation. Trends in Ecology \& Evolution, 19, 305-308.

TAYLOR, C. (1998) Environmental education in primary education: status and trends in southern and eastern Africa. Environmental Education Research, 4, 201-215.

WALlis, J. \& LONSDORF, E.V. (2010) Summary of recommendations for primate conservation education programs. American Journal of Primatology, 72, 441-444.

Washington, H., Baillie, J., Waterman, C. \& Milner-Gulland, E.J. (2015) A framework for evaluating the effectiveness of conservation attention at the species level. Oryx, 49, 481-491.

Waylen, K.A., Fischer, A., McGowan, P.J.K., Thirgood, S.J. \& Milner-Gulland, E.J. (2010) Effect of local cultural context on the success of community-based conservation interventions. Conservation Biology, 24, 1119-1129.

Westbrook, J., Durrani, N., Brown, R., Orr, D., Pryor, J., Boddy, J. \& Salvi, F. (2013) Pedagogy, Curriculum, Teaching Practices and Teacher Education in Developing Countries. Final Report. Education Rigorous Literature Review. Department for International Development, UK. Http://eppi.ioe.ac.uk/cms/Default. aspx?tabid=3433 [accessed 26 May 2017]

Wright, J.H. (2010) Use of film for community conservation education in primate habitat countries. American Journal of Primatology, 72, 462-466.

\section{Biographical sketches}

KRISTEN LUKAS's research interests include animal behaviour and conservation psychology. Austin Leeds's research interests include animal behaviour and conservation psychology. Michelle SLAVIN's interests include sustainable development and conservation education. JoHN TinkA's interests include sustainable development and conservation education. CORINNE Kendall's research interests include wildlife ecology and conservation education. 